"Peculiarities of ensuring financial sustainability of the Ukrainian banking system"

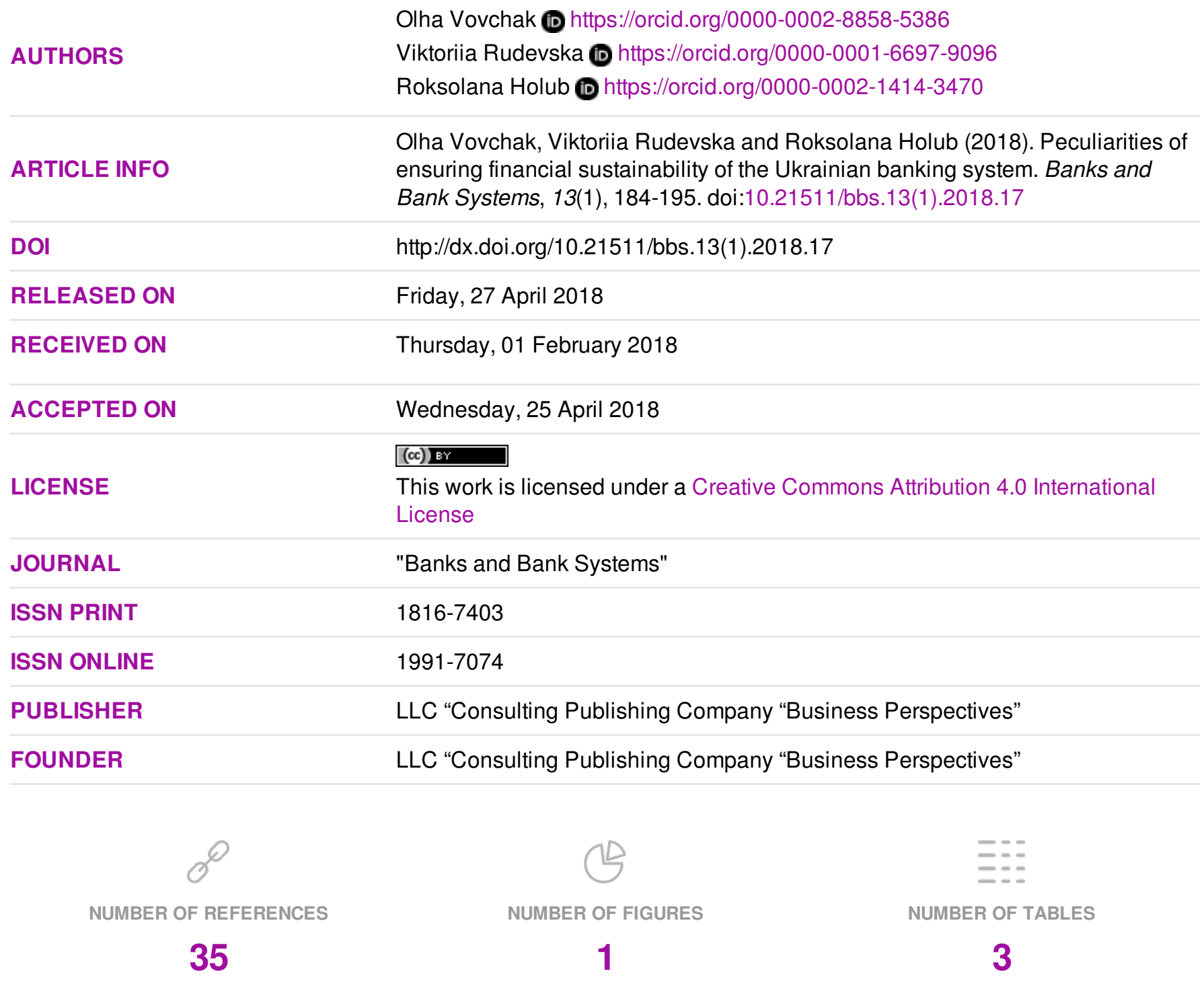

(c) The author(s) 2022. This publication is an open access article. 


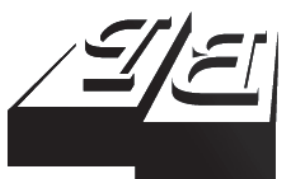

BUSINESS PERSPECTIVES

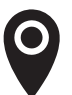

LLC "CPC "Business Perspectives" Hryhorii Skovoroda lane, 10, Sumy, 40022, Ukraine

www.businessperspectives.org

Received on: $1^{\text {st }}$ of February, 2018 Accepted on: $25^{\text {th }}$ of April, 2018

(C) Olha Vovchak, Viktoriia Rudevska, Roksolana Holub, 2018

Olha Vovchak, Dr., Prof., the Head of Finance, Banking and Insurance Department, Banking University, Ukraine.

Viktoriia Rudevska, Ph.D. (Economics), Associate Professor, the Associate Professor of Finance, Banking and Insurance Department, Banking University, Ukraine.

Roksolana Holub, Ph.D. (Economics), Associate Professor, the Associate Professor of Finance, Banking and Insurance Department, Banking University, Ukraine.

\section{PECULIARITIES OF ENSURING FINANCIAL SUSTAINABILITY OF THE UKRAINIAN BANKING SYSTEM}

\begin{abstract}
Ensuring and strengthening the financial sustainability of banks is a difficult and not completely resolved task. It is inherent not only to developed countries, it has also become nationally important in Ukraine, which was largely predetermined by the specifics of the domestic banks development. This is explained, in particular, by the banking institutions' focus mainly on the relatively short-term activity, the need to work under high risk, resulting from economic and political instability in the country. Therefore, nowadays, it is urgent for each Ukrainian bank to focus on the main strategic objective - effective management and ensuring financial sustainability. The purpose of this study is to assess the current state and identify the features of ensuring financial sustainability of the banking system of Ukraine.

It was pointed out in the study that the negative tendency to increase the number of in solvent commercial banks during 2012-2017 indicates problems with providing financial sustainability to commercial banks. The tendencies have been revealed that testify to the problems of the banking system capitalization in Ukraine, which greatly affects its financial stability. Given the analysis of indicators of banks financial sustainability that characterize the bank capital adequacy, the conclusion is made on ambiguous assessment of sufficient level of capitalization, since despite the correspondence of most values of coefficients to the indicators, there is a lack of capitalization of the domestic banking system and equity capital concentration. In general, the results made it possible to identify trends in the development of capital ratios and financial sustainability indicators and to shape appropriate measures to increase the level of capitalization in order to ensure the financial sustainability of the banking system.
\end{abstract}

\section{Keywords}

banking system, financial sustainability, equity capital, capitalization of the banking system, bank capital adequacy, financial sustainability indicators

\section{JEL Classification G21, M12, M52}

\section{INTRODUCTION}

The banking system of each country, regardless of its economic model and social relations, plays a key role in ensuring cash flows. Sustained development of the economy, in particular its important part - the banking system, is a major priority in the context of economic globalization. Today, the impact of financial, economic and political crises is actualizing the issue of ensuring stable economic development in Ukraine, which depends to a large extent on the banking sector reliability. The determining factors in shaping the trust of depositors, partners, and investors to banks are their financial sustainability and stable development. In particular, both financial sustainability and sustainable development must be achieved not only in the short term, but also as a result of the strategic objectives implementation.

distributed under the terms of the Creative Commons Attribution 4.0 International license, which permits unrestricted re-use, distribution, and reproduction in any medium, provided the original work is properly cited.
Due to the banking market destabilization influenced by political and economic crises, ensuring financial sustainability not only for a single bank but also for the banking system as a whole plays a key role. The 
degree of redistributive processes in the economy, the amount of financial resources directed towards lending to the economy, and the formation of an investment climate will depend on the level of the sustainability of the banking system and each individual bank. Sustainability is important for an individual bank, as increased competition and the use of aggressive banking policies require new approaches to the development and implementation of banking products, financial instruments and the attraction of additional capital (Zveruk \& Boieva, 2017).

As practice shows, a number of banks in Ukraine are incapable of confronting threats, adapting to the constantly changing market conditions and manifestations of potential risks of destabilization. As a result, there is a reduction in the number of operating banks, but a particularly threatening is the decrease in the number of banks with foreign capital: investors refuse to operate in Ukraine. The events of banks insolvency, usually caused by a financial crisis and the ultimate result of reducing financial sustainability, also give rise to think about the problem of its support and effective management, since the elimination of at least one large bank has, of course, negative social and economic consequences both for the country's economy, and partly for the economies of the partner countries. In addition, it can lead to panic among the population and result in a chain reaction of bankruptcies in the banking system. Therefore, the financial sustainability of the banking system as a whole and of a particular commercial bank should be subject to strict control by the banking regulators, as well as the object of special attention from the public (Shulzhenko, 2012). In view of this and given the current trends in the banking activities in the globalized economic environment, ensuring financial sustainability as a basis for the effective functioning of the Ukrainian banking system, which should be one of the priorities of the National Bank of Ukraine, becomes of paramount importance.

\section{LITERATURE REVIEW}

Many scholars analyzed the issue of banks financial sustainability and its evaluation. So, Swanepol and Smit (2016) in their study have shown that the banking system sustainability plays a significant role in the overall economic development. AlShawabkeh and Kanungo (2017) analyze the improving banking system sustainability through assessing the credit risk and improving bank decision making.

The scientific analysis of the interpretation of the "financial sustainability of the banking system" in the economic literature proves that today there is no single approach to its definition. In particular, Vitlinskyi and Pernarivskyi (2000) consider financial sustainability as compliance (noncompliance) with the main planning (normative) aggregate indicators that synthesize the characteristics of the economic components of financial sustainability: the volume and structure of equity, income and profit, the rate of return on equity, sufficient liquidity, multiplicative efficiency of equity capital, and added value creation. Baranovskyi (2007) characterizes financial sustainability of the banking system as an ability to withstand external and internal influences, maintaining a stable balance and reliability over time. Panasenko (2009) considers the financial sustainability of the banking system as the measure of completeness and quality of solving the task of the banking system, fulfilling its mission, which ensures achieving a positive financial result, since the task of banks is not only to fulfill financial indicators. Sheludko (2000) considers financial sustainability as a dynamic ability of the bank as a system for the full transformation of resources and risks (with maximum efficiency and minimum risk) to fulfill its functions, while bearing the influence of the external and internal factors. The author also believes that such an interpretation relates to a banking system. According to Fetisov (2002), the financial sustainability of the banking system is a qualitative characteristic, it is a development in which its essence and purpose are realized in the economy. In a sustainable economic system, not one-time positive change, not temporary success in functioning or temporary stabilization, not the success of individual banks, but the dynamic development of all elements of the banking system take place.

These definitions in an inadequate degree take into account the variability of the banking system's 
functioning environment, the impact of financial and economic crises, and the cyclical nature of any economic system development, when it is extremely difficult to predict changes under globalization (Marych \& Marych, 2017). Among the financial and economic factors, the monetary policy of the National Bank of Ukraine (NBU) and its instruments have a significant impact on the financial sustainability of banking institutions and the system as a whole. In particular, an increase in the minimum size of mandatory reserves reduces the bank's lending capacity, but greatly strengthens its financial stability. Reducing the discount rate, in turn, cheapens the credit resources received from the National Bank, and open market operations help maintain liquidity. In the course of the crisis, the NBU focused its efforts on ensuring timely settlement by banks, reducing the outflow of funds from the banking system and balancing the situation on the currency market (Zveruk \& Boieva, 2017).

Batrakova (2007) and Lavrushyn (2005) examined the financial sustainability of commercial banks and identified a number of factors that had a significant impact on it. Baranovskyi (2007) researched the sustainability of the domestic banking system; Dovgan (2012) examined problems of assessing the financial sustainability of the banking system. Vitlinskyi and Pernarivskyi (2000) determined financial sustainability as a systemic characteristic of a commercial bank. Dziubliuk and Mykhailiuk (2009) analyzed the financial sustainability of banks as the basis for effective functioning of the credit system.

Carson and Ingves (2001) and Demirguc-Kunt, Detragiache and Tressel (2006) highlighted peculiarities of assessing sustainability of the financial sector and financial and credit institutions, in particular in foreign banking practices in accordance with the Financial Soundness Indicators: Compilation Guide, which are accepted by many countries of the world as highly effective, despite the difficulty of calculating some indicators and the specificity of the statistical information necessary for their conduct. The Ukrainian financial sector also utilizes the proposed methodology for calculating the IMF's financial indicators to assess sustainability. However, according to Zvieriakov and Kovalenko (2012), in order to achieve positive results, such recommendations should be adapted to domestic realities, taking into account the peculiarities of the national banking system and the principles of information disclosure.

Ukrainian and foreign scholars devoted considerable attention to the assessment and provision of certain components of financial sustainability in the banking sector: banking risks (Bobyl, 2014; Vaskovych 2006; Shermer, 2013), business activity and profitability (Sheludko, 2002), sustainability of resource and capital bases (Zavadska, 2011; Lotobayeva, 2006), etc. Bobyl (2014), in his work, drew a parallel between the financial condition of the bank and its financial sustainability. He paid considerable attention to the assessing the risks of banking activities, which, in his opinion, have a significant impact on the maintaining the financial sustainability of banks.

According to Zavadska (2011), in managing the bank financial sustainability, attention should be paid to its components, such as capital and resource sustainability, as they ensure the bank's viability and its susceptibility to potential risks. However, Sheludko (2002) highlights performance indicators of the bank as the most important indicators in assessing its financial sustainability based on a multivariate approach. Kornyliuk (2013) is of a similar view, noting that the scale and performance of the bank for a certain period are the main indicators of its steady position on the market.

Diaconu and Oane (2014) selected four variables main determinants which influence bank financial sustainability: inflation (proxy for macroeconomic general situation), GDP growth (proxy for macroeconomic general situation), BET rate (proxy for financial market situation) and interbank offering rate for three months (proxy for banking sector situation).

Kliusko (2013), Cherep (2011) and Myronchuk (2012) examined the theoretical and methodological foundations for estimating and forecasting financial sustainability through the use of economic and mathematical models (including by constructing an integral indicator); development of a comprehensive system for managing financial sustainability at macro and micro levels and possible ways to strengthen it. 
Lotobayeva and Nasonova (2006) considered it important to select financial indicators that would be the most informative and stand together in describing the financial condition of the bank. Shpakovska (2013) noted that while assessing the bank financial sustainability it is necessary to follow such key principles: complexity, characteristics of the financial sustainability of the bank in priority areas of activity, and identifying the main trends in changing the financial sustainability of the bank.

Ramskyi, Loiko, Sobolieva-Tereshchenko, Loiko and Zharnikova (2017) believe that the effective mechanism for influencing the financial sustainability of domestic banks is the implementing the Basel III recommendations, which is the basis for the prospect and need for constant attention to the banking sector, including all public, private and foreign banks, in order to strengthen the stability of the country's financial system.

The issue of competition has also been reflected in the scientific literature. So, Boyd and Nicolo (2005) argue that increasing competition and reducing market power affect banks to have more capital and take less credit risk by increasing their financial sustainability. Martinez-Miera and Repullo (2010) talk about a non-linear, upsidedown U-shaped link between competition and financial stability of a bank.

The synthesis and analysis of the works published on this subject made it possible to conclude that today there is no single integrated approach to determining the level of financial sustainability of banks. First and foremost, there are different views of scientists regarding the list and composition of indicators necessary for use as financial sustainability indicators. The issues of the formation of conceptual and methodological approaches to determining the financial sustainability of the banking system are not sufficiently developed in scientific and organizational, methodological and practical aspects.

\section{RESULTS}

The basis of the banking system is the second tier banks, while its first level is shaped by central banks, which perform oversight functions, contributing to the efficient operation of banks. Nowadays, the financial sustainability of each bank is the key to the stable development of the banking system. Therefore, further it is necessary to focus on the activities of the second-tier banking system - commercial banks, whose strategic goal is to develop partnerships with clients, focus their efforts on meeting their needs and ensure their own financial sustainability (Marych \& Marych, 2017).

According to the National Bank of Ukraine, as of January 1, 2018, 82 commercial banks operated on the territory of Ukraine, of which, with the participation of foreign capital - 38 or $46 \%$ of the total number of banks, including 18 banking institu-

Table 1. Dynamics of structural changes in the banking sector of Ukraine in 2012-2017

Source: Calculated by the authors based on the NBU statistical data.

\begin{tabular}{|c|c|c|c|c|c|c|}
\hline Bank category & $\underset{2013}{\text { January } 1,}$ & $\begin{array}{c}\text { January } 1, \\
2014\end{array}$ & $\underset{2015}{\text { January }} 1$, & $\underset{2016}{\text { January }} 1$, & $\underset{2017}{\operatorname{January}} \mathbf{1}$ & $\underset{2018}{\operatorname{January}} 1$, \\
\hline Solvent banks & 180 & 147 & 117 & 96 & 90 & 82 \\
\hline - change (growth) & - & $(-33)$ & $(-30)$ & $(-21)$ & $(-6)$ & $(-8)$ \\
\hline State-owned banks & 7 & 7 & 7 & 6 & 6 & 6 \\
\hline -change (growth) & - & (0) & (0) & $(-1)$ & $(0)$ & $(0)$ \\
\hline Foreign-owned banks & 25 & 25 & 25 & 25 & 25 & 25 \\
\hline - change (growth) & - & (0) & (0) & (0) & (0) & $(0)$ \\
\hline Privately owned banks & 148 & 115 & 85 & 65 & 59 & 51 \\
\hline - change (growth) & - & $(-33)$ & $(-30)$ & $(-20)$ & $(-6)$ & $(-8)$ \\
\hline Insolvent banks & 0 & 16 & 3 & 4 & 4 & 4 \\
\hline - change (growth) & - & $(16)$ & $(-13)$ & (1) & (0) & $(0)$ \\
\hline Banks in liquidation & 2 & 21 & 64 & 84 & 90 & 90 \\
\hline - change (growth) & - & (19) & (43) & (20) & (6) & (0) \\
\hline
\end{tabular}


Table 2. Ukrainian banks, which are in reorganization and liquidation as of January 1, 2017

Source: Compiled by the authors based on the NBU statistical data.

\begin{tabular}{|c|c|c|c|}
\hline Bank name & $\begin{array}{l}\text { Date of NBU } \\
\text { decision to declare } \\
\text { the bank insolvent }\end{array}$ & $\begin{array}{l}\text { Date of decision of the Deposit } \\
\text { Guarantee Fund executive directorate } \\
\text { on the introduction of the Provisional } \\
\text { Administration }\end{array}$ & $\begin{array}{l}\text { Date of NBU } \\
\text { decision on } \\
\text { liquidation }\end{array}$ \\
\hline PJSC Platynum Bank & January 10, 2017 & January 11, 2017 & February 23, 2017 \\
\hline PJSC Bank Narodnyi Kapital & January 19, 2017 & January 19, 2017 & March 7, 2017 \\
\hline PJSC Fortuna-bank & January 26, 2017 & January 27, 2017 & February 21, 2017 \\
\hline PJSC Vektor bank & March 2, 2017 & March 2, 2017 & March 21, 2017 \\
\hline PJSC Finbank & April 7, 2017 & April 9, 2017 & April 27, 2017 \\
\hline PJSC Diamantbank & April 24, 2017 & April 24, 2017 & June 23, 2017 \\
\hline PJSC Novyi & July 13, 2017 & July 13, 2017 & August 31, 2017 \\
\hline PJSC CB Hefest & August 1, 2017 & & \\
\hline
\end{tabular}

tions, or $22 \%$ of the total - with $100 \%$ foreign capital. According to Table 1, the number of solvent commercial banks decreased during 2012-2017 (from 180 to 82 ), the peak periods of bank failures were 2015-2016 (in 2015, 43 commercial banks and in 2016, 20 commercial banks went into liquidation phase).

Consequently, the negative tendency to increase the number of insolvent commercial banks during 2012-2017 indicates the problems of ensuring commercial banks with financial sustainability. Table 2 shows the list of banks that are currently in the process of reorganization; banks recognized as insolvent and to which the Deposit Guarantee Fund has introduced the provisional administration; and banks in liquidation.

According to Table 2, today, banks in Ukraine are at risk of financial sustainability failure. One of the indicators characterizing the financial sustainability of the banking system is the volumes of the resource base of banking institutions, the main element of which is capital. The dynamics of the growth rate of the equity capital of the Ukrainian banking system shows that since 2009, banks almost stopped the growth of capital, which has led to such a significant decline. In 2010-2013, banks increased their equity capital by raising shareholder deposits in terms of subordinated debt. In 2014 and 2015, though significant investments were made by shareholders, but the banks suffered enormous losses, and the adverse political and economic situation in the country, inflation and the ever-increasing exchange rate of the national currency had a negative impact on the financial sustainability of banks. Analyzing the indicators of changes in the volume of equity capital of domestic banks, it should be noted that compared to 2012 (as of January 1, 2013), the equity capital of banks in Ukraine decreased by UAH 45,536.4 mln (or by 27\%) and as of January 1, 2018 it amounted to UAH 163,597 million. However, the total amount of equity capital of banks remains lower than the authorized capital, the volume of which as of January 1, 2018 amounted to UAH 495,377 million, which is due to significant amounts of accumulated losses during the crisis years. During the period under study, the ratio of equity capital to GDP decreased: from $12 \%$ in 2012 to $5.48 \%$ in 2017, while in the EU countries this indicator is about $40 \%$.

In 2016 and 2017, the banking system, although suffering enormous losses, already had a positive indicator at the expense of an increase in the authorized capital (more than doubled), a significant reduction in the number of banks - during this period, 33 insolvent banks were withdrawn and PrivatBank was nationalized, and, as a result, state funds into the banking system of Ukraine were injected.

The above tendencies indicate, first of all, the problems of capitalized banking system of Ukraine, which greatly influenced the level of the financial sustainability. Insufficient bank capitalization and the inability of shareholders to provide the appropriate level of financial support were one of the most important reasons for considering domestic banks as insolvent, in addition to the violating the legislation regulating the prevention and counteraction to the legalization (laundering) of proceeds from crime. Contributing to the problem of bank 
capitalization is the fact that in 2017, the minimum amount of authorized capital at the time of state registration of a legal entity intending to conduct banking activities increased from UAH 120 million up to UAH 500 million, and the NBU has developed a schedule for gradually bringing the authorized capital into compliance with the requirements.

The National Bank of Ukraine, in order to support banking activities stability and to analyze the financial sustainability of commercial banks, approved the "Instructions for the Procedure for Regulating the Activities of Banks in Ukraine", which sets out the economic standards that are mandatory for all banking institutions, which makes it possible to fairly assess the financial position of a commercial bank. Table 3 shows indicators of economic standards for 2015-2018.

During the period analyzed, the composition of economic standards has changed significantly: S3 and S3-1 have been canceled; a new standard S9 was introduced in accordance with the Resolution of the Board of the National Bank of Ukraine dated June 8, 2015, No. 361, and the previous S9 and S10 cease to be calculated. It should be noted that these figures were within the normal range on the last date of calculation.

As Table 3 shows, during the analyzed period the decline of the regulatory capital of commercial banks is about $34 \%$. However, in 2018, compared with 2017, this indicator has a positive trend and has grown by almost $20 \%$, indicating an increase in the ability to provide deposit protection, and hence to improve the financial sustainability of banking activities.

The regulatory capital adequacy ratio for 20142018 has grown and amounted to $16.49 \%$, which indicates the ability of a bank to timely and fully pay off its liabilities arising from trade, credit or other monetary operations. However, as of April 1,

Table 3. Indicators of economic standards as of April 1, 2015 - April 1, 2018

\begin{tabular}{|c|c|c|c|c|c|c|c|}
\hline No. & Standard & Standard value & $\begin{array}{c}\text { April 1, } \\
2014 \\
\end{array}$ & $\begin{array}{c}\text { April 1, } \\
2015 \\
\end{array}$ & $\begin{array}{c}\text { April 1, } \\
2016 \\
\end{array}$ & $\begin{array}{l}\text { April 1, } \\
2017\end{array}$ & $\begin{array}{c}\text { April 1, } \\
2018\end{array}$ \\
\hline $\mathrm{S} 1$ & $\begin{array}{l}\text { Regulatory capital (RC) } \\
(\mathrm{UAH} \text { mln) }\end{array}$ & UAH 500 mln & $179,976.4$ & $115,302.8$ & $127,006.2$ & $99,029.8$ & $118,991.8$ \\
\hline $\mathrm{S} 2$ & $\begin{array}{l}\text { Regulatory capital } \\
\text { adequacy }\end{array}$ & At least $10 \%$ & 14.80 & 8.35 & 12.03 & 13.72 & 16.49 \\
\hline S3 & $\begin{array}{l}\text { Regulatory capital to } \\
\text { aggregate assets ratio }\end{array}$ & At least $9 \%$ & 12.84 & \multicolumn{4}{|c|}{ Not calculated } \\
\hline S3-1 & $\begin{array}{l}\text { Standard (coefficient) } \\
\text { of } R C \text { to liabilities ratio }\end{array}$ & At least $10 \%$ & 15,98 & \multicolumn{4}{|c|}{ Not calculated } \\
\hline S4 & Instant liquidity & At least $20 \%$ & 48.81 & 49.11 & 76.52 & 61.93 & 56.95 \\
\hline S5 & Day-to-day liquidity & At least $40 \%$ & 79.63 & 72.92 & 84.13 & 115.54 & 103.11 \\
\hline S6 & Short-term liquidity & At least $60 \%$ & 83.23 & 78.76 & 89.54 & 95.76 & 92.87 \\
\hline S7 & $\begin{array}{l}\text { Credit risk limits per } \\
\text { one counterparty }\end{array}$ & $\begin{array}{l}\text { No more than } \\
25 \%\end{array}$ & 23.58 & 23.42 & 22.87 & 22.31 & 20.19 \\
\hline S8 & High credit risks & $\begin{array}{l}\text { No more } \\
\text { than eightfold } \\
\text { regulatory capital }\end{array}$ & 259.44 & 651.32 & 345.47 & 284.08 & 184.23 \\
\hline S9 & $\begin{array}{l}\text { High credits, } \\
\text { guarantees and } \\
\text { securities given to one } \\
\text { insider }\end{array}$ & No more than $5 \%$ & 0.26 & 0.13 & \multicolumn{3}{|c|}{ Not calculated } \\
\hline S9 & $\begin{array}{l}\text { High credit risks for } \\
\text { operations with bank- } \\
\text { related individuals }\end{array}$ & $\begin{array}{l}\text { No more than } \\
25 \%\end{array}$ & \multicolumn{2}{|c|}{ Not calculated } & 37.03 & 28.72 & 15.14 \\
\hline $\mathrm{S} 10$ & $\begin{array}{l}\text { High aggregate } \\
\text { credits, guarantees } \\
\text { and securities given to } \\
\text { insiders }\end{array}$ & $\begin{array}{c}\text { No more than } \\
30 \%\end{array}$ & 1.63 & 1.08 & \multicolumn{3}{|c|}{ Not calculated } \\
\hline $\mathrm{S} 11$ & $\begin{array}{l}\text { Investment in securities } \\
\text { on a per-institution } \\
\text { basis }\end{array}$ & $\begin{array}{l}\text { No more than } \\
15 \%\end{array}$ & 0.03 & 0.01 & 0.002 & 0.00010 & 0.00010 \\
\hline $\mathrm{S} 12$ & $\begin{array}{l}\text { Aggregate amount of } \\
\text { capital invested }\end{array}$ & $\begin{array}{l}\text { No more than } \\
60 \%\end{array}$ & 3.41 & 2.13 & 0.80 & 0.39 & 0.14 \\
\hline
\end{tabular}


2015 , this indicator amounted to $8.35 \%$, which is $1.65 \%$ lower than the normative value.

The economic norms of liquidity of S4 and S5 during the analyzed period increased by $14.3 \%$ and $22.8 \%$, respectively. However, compared to 2017, their decline was observed. In particular, the rate of instant liquidity in 2018 decreased to $56.95 \%$, indicating the banks' concerns regarding maintaining the required volume of highly liquid assets, which ensure fulfillment of current obligations within one day. The current liquidity ratio in the current year was $103.11 \%$, which is $12.43 \%$ less than in the previous year. However, since this indicator was within the normal range during the period under review, it should be noted that commercial banks adhered to the minimum amount of bank assets to ensure that the current liabilities were fulfilled during one calendar month.

The short-term liquidity ratio grew steadily during 2014-2017, indicating a sufficient amount of assets in commercial banks in Ukraine to meet the obligations for the period under investigation. However, by 2018 , it has fallen by $2.89 \%$, but remains within the normal range.

Credit risk limits S7 and S8 for 2014-2018 decreased by $14.38 \%$ and $30 \%$, respectively. This indicates a reduction in credit risk that may arise in the event of non-compliance by individual counterparties with their obligations and limiting the concentration of credit risk by a particular counterparty or a group of related counterparties.

It can be seen from the analysis that S11 and S12 fall steadily. In particular, the standard for investing in securities separately for each institution as of March 1, 2016, compared with 2015, fell by 0.009 , and in 2018 , compared with 2017 , by 0.0001 , respectively. With regard to $S 12$, in 2016 it dropped by 1.34 percent, and in 2017 - by almost 0.20 percent. This indicates that the investment activity of banks is not supported in recent years.

Since most of the bank's financial sustainability indicators are based on determining capital adequacy to cover banking risks and on assessing the capital structure that determines the qualitative composition of balance capital, it is necessary to consider a group of key indicators of financial sustainability of banks based on the bank capital adequacy, namely, the capitalization (equity concentration), the ratio of the authorized capital to equity capital, and the coefficient of efficient use of resources.

The indicator of capitalization (concentration of equity capital) determines the level of capital in the structure of total liabilities, that is, in the total amount of sources of the bank. On the other hand, the excessive growth of the indicated coefficient points at the non-business activity (inactivity) of the bank in terms of attracting resources and developing a client base. According to the NBU official data, in the period from 2008 to 2014, an increase in equity capital in the structure of liabilities took place from $11.6 \%$ to $15.8 \%$, that is, it can be concluded that Ukrainian banks during the period of the global financial crisis and after it increased the share of capital in their common sources, which met the new Basel Committee requirements to prevent the global financial crises. However, already in 2014-2016, the negative tendency of concentration of equity capital from $15 \%$ to $7.7 \%$ can be traced, this situation can be explained by political instability, military actions in the eastern Ukraine, doubling the dollar exchange rate (from UAH 12 in 2014 to UAH 25 in 2016) and a significant reduction in the number of banks in Ukraine. In 2017, the capitalization of the Ukrainian banking system has increased to $12.2 \%$, but this value of the capitalization index has not reached its recommended values (according to the Basel Committee requirements, it is $15-20 \%$ ).

A bank dependence on its founders characterizes the authorized capital to equity capital ratio. According to current practice, the amount of funds invested in the banking institution development should be twice as much as the founders' contributions. Minimum value of this indicator is $15 \%$, maximum - 50\%. According to authors' calculations, since 2009, there has been a small increase in the authorized capital, which is the result of injection of additional funds and revaluation as a result of the rate growth (the share of foreign capital in the banking system of Ukraine was 35-40\%). Since 2015, this ratio begins to grow rapidly to 2.1 in 2016 and 2.57 in 2017, that is, there were significant injections of funds into the authorized capital by founders, primarily due to subordinated debt, 
which in 2015-2016 was more than UAH 60 billion. Also, the fact that the banks were supposed by July 2017 to increase their regulatory capital to 120 UAH million has had its impact. Equally important and decisive was the fact that the 2015-2017 period was lossmaking for the Ukrainian banking system (as of January 1, 2017, the losses amounted to a record UAH 196 billion, and in the end of 2017 the banking sector also had losses in the amount of UAH 24.4 billion due to significant amounts of deductions in reserves). All this testifies to the fact that the banks were extremely dependent on their founders and required significant capital inflows.

It is essential to note that an important component in the diagnosis of the bank's capitalization is the efficient use of the resource, as evidenced by indicators such as return on equity (ROE) and return on assets (ROA). However, considering the losses of the banking system, one cannot speak about the profitability, but about the loss-making use of resources. So, the ROE value for 2017 was negative $(-15.96 \%)$, and ROA was also negative $(-1.94 \%)$, however, as compared to 2016, the loss-making rate decreased, because that year, ROE reached $-116,74 \%$, and ROA $-12.60 \%$, indicating some increase in resource efficient use, and in general, some strengthening of financial sustainability. At the same time, failure to comply with the recommended level of these indicators indicates the need to improve the functioning of investment objects by banks.

Consequently, as it follows from the analysis, if the banking system tends to decrease capital ratios, market values and capitalization ratios, it needs to take measures to increase capitalization in order to ensure the financial sustainability of the banking system.

The independence, and, consequently, sustainability of banks as to market changes is assessed by analyzing the regulatory capital to liabilities ratio. The coefficient of financial independence (coverage of liabilities) characterizes the degree of coverage of borrowed funds, that is, the level of a bank dependence on borrowed funds. The calculations show that since 2009 this indicator starts to grow and in the period of 2011-2012 it is fixed at the level of $20 \%$, that is, the growth of financial sustainability of the Ukrainian banking system was observed mainly due to the increase of the authorized capital. Since 2015, the rate of financial independence has been decreasing due to the growth of liabilities and the coverage of bank losses with a share of capital. Summing up, it can be argued that the arrhythmia of the indicator indicates the risk of losses in terms of shaping the stable resource base, and also points to current liquidity problems that banks faced in the respective periods of crisis.

Some banks, in order to analyze the financial sustainability, use a capital multiplier, which reflects the degree of coverage of assets by equity and indicates what amount of hryvnia assets should be provided by each hryvnia of equity (that is, the funds of the bank owners) and, accordingly, what proportion of banking resources can be formed in terms of debt instruments. This indicator of financial dependence is an indicator of financial sustainability, which also indicates the ability of the bank to conduct a projected activity in the long run. The indicator is reversed to the financial autonomy indicator. Since 2008, the capital multiplier decreases from 8.6 to 6.6 in 2014. This suggests, first of all, that the growth rate of assets exceeds the growth rate of share capital and, secondly, the presence of tendencies to reduce the use of opportunities to attract them from the share capital. Since 2014 till 2016, this indicator grows and reaches its maximum value - 13.0, that is, the higher its value, the less stable the bank, but the growth of this factor stimulates the growth of equity profitability. Starting from 2016, the value of the financial dependence coefficient is reduced to 7.6 according to the Q32017 results, which testifies to the caution of bank management in terms of active operations.

The coefficient of financial risk (financial leverage) characterizes the amount of attracted capital in the amount of $1 \mathrm{UAH}$ of equity capital and is a reversed indicator to the reliability coefficient and reveals the ability of the bank to raise funds in the financial market. During 2010-2014, this indicator ranged from 5.4 to 7.6. In 2015-2016, the growth rate of this ratio is up to 12.03 , indicating an increase in the banks dependence on borrowed sources, a partial loss of financial autonomy, and the fact that banks have increased their activity in attracting funds in the money market, even at high levels of their own capital. Starting from 


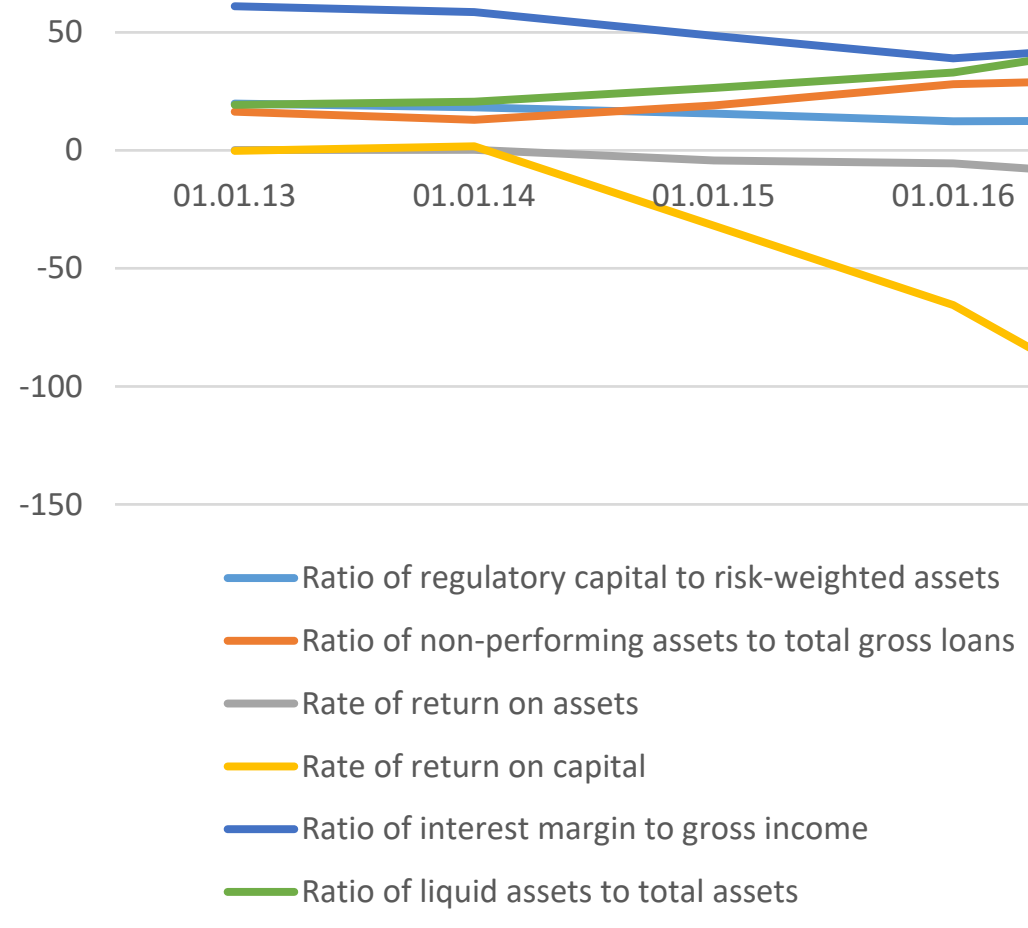

Figure 1. Dynamics of the financial sustainability indicators of the Ukrainian banking system for January 1, 2013 till January 1, 2018, \%

2017, the situation is somewhat stabilized and the indicator of the financial leverage is reduced to 6.6, mainly due to the additional capitalization of the banking sector.

Summarizing, consideration should be given to indicators of financial sustainability of the Ukrainian banking system over the past 5 years (Figure 1). Indicators of financial sustainability are those of the current financial status and stability of financial institutions and their counterparties from the sector of non-financial corporations and the household sector. The data include information on the main indicators of the financial sustainability of deposit corporations (banks) regarding capital adequacy, asset quality, profits and profitability, liquidity, market risk sensitivity and recommended financial sustainability indicators, and are calculated based on the output data for their compilation contained in the official NBU statistics.

As can be seen from Figure 1, most of the calculated indicators tend to decrease, especially as regards the ratio of returns to assets and capital. This was due to the fact that financial-economic and political crises had a significant impact on the financial sustainability of the Ukrainian banking system. Thus, it is possible to draw conclusions about the poor performance of commercial banks. Banks suffer losses, resulting in a reduction in their capital and a continuing tendency to deteriorate their financial sustainability and performance.

The assessment of the financial sustainability indicators of banks and their capitalization assessment based on the data on bank capital indicate an ambiguous estimate of sufficient capitalization level, as despite the most coefficients correspondence, there is a lack of the domestic banking system capitalization and the concentration of equity capital. An increase in the authorized capital in equity indicates an increase in the banks' dependence on their shareholders. It is also possible to note the security of client funds and the provision of credit operations with equity, therefore, there is a potential opportunity for additional increase in the volume of clients' funds and loan portfolio 
to maintain the financial sustainability of banks. However, Ukrainian banks are quite difficult to withstand crisis periods, they recover from them for a long time, and often abandon higher profitability in order to minimize the riskiness of their operations.

With regard to liquidity indicators, according to NBU data on liquidity ratios, commercial banks manage to maintain liquidity at an appropriate level due to the fact that capital structure is dominated by assets in primary and secondary reserves - they are liquid, but not profitable (the values of S4, S5, and S6 standards substantially exceed the threshold values). At the same time, the volume of profitable credit and investment operations in banks of Ukraine has significantly decreased. A high level of uncertainty about further economic development and a limited range of reliable borrowers are among the main factors hindering the restoration of lending.

The response against the challenges of the global financial and economic crisis was the development in 2010 of Basel III, new principles of banking regulation and supervision, the provisions of which are aimed at improving the quality of risk and capital management in banking institutions and serve as legislative prerequisites for ensuring financial sustainability of banks, taking into ac- count the conditions for the development of the world economy and globalization processes. At the same time, it should be borne in mind that factors, such as the business model and strategy of the bank, the structure of capital and liquid assets, current indicators of equity capital adequacy and liquidity, the degree of reliability, can have a significant impact on ensuring an adequate level of financial sustainability of banks and on considering new Basel III principles.

In the current context of integration processes, the interpenetration of world economies occurs, resulting in an influx of foreign capital into the Ukrainian banking sector, which significantly influences the functioning of the banking system and its financial sustainability. In particular, during a downturn, the presence of banks with foreign capital can become a source of sustainability for the banking systems of the recipient country of bank capital, since the parent structures can recapitalize their subsidiaries and maintain a sufficient level of financial sustainability compared to domestic banks. However, branches of banks with foreign capital are more vulnerable to external conditions. Given the dependence of banks with foreign capital on external financing in particular, its restrictions make them uncompetitive in the market and stimulate to reduce their credit operations.

\section{CONCLUSION}

The scientific research conducted gives grounds to assert that the financial sustainability of a commercial bank is extremely sensitive to the influence of both external and internal factors. First of all, crises slow down the development of national economies in general and banking sectors in particular. The impact of the crisis on the banks results in the problem with the liquidity of commercial data. Thus, in the context of the crisis, the possibility of securing the financial sustainability of the domestic banking system is limited, and its support is possible only with the stabilization of the financial, economic and political situation in the country.

In Ukraine, the effects of the crisis and political instability have not been completely overcome and have a significant impact on the banking system of Ukraine. Therefore, the financial sustainability of the banking sector is not sufficiently stable and requires an increase in capital, which today cannot yet fully protect the bank from potential risky losses.

Increasing the level of the banking system capitalization must provide a purposeful activity of the National Bank of Ukraine, focused on increasing the efficiency of the banks that will promote adequate risk coverage with a gradual increase of the capital, restore confidence in the banking system and increase the capitalization of the Ukrainian banking system, increase the domestic banks competitiveness 
in the global financial market and ensure the financial sustainability of the national economy and financial security of the country as a whole.

On the part of supervisors, it is important to introduce commercial banks' performance norms and financial sustainability indicators that are used in foreign banking practices.

The banks themselves should redouble their attention to working with problem loans and diversifying banking assets by expanding activities and ensuring transparency of the bank's operations, that is, financial information should be accessible to wide audience.

\section{REFERENCES}

1. Al-Shawabkeh, A., \& Kanungo, R. (2017). Credit risk estimate using internal explicit knowledge. Investment Management and Financial Innovations, 14(1), 5566. http://dx.doi.org/10.21511/ imfi.14(1).2017.06

2. Baranovskyi, O. I. (2007). Стійкість банківської системи України [Stiikist bankivskoi systemy Ukrainy]. Finansy Ukrainy, 9, 75-87.

3. Basel III: A global regulatory framework for more resilient banks and banking systems revised version June 2011, BCBS, May 2011.

4. Batrakova, L. G. (2007). Экономический анализ деятельности коммерческого банка [Ekonmicheskiy analiz deyatelnosti kommercheskogo banka. Elektron. tekstovyye dannyye] (368 p.). M.: Logos, Universitetskaya kniga. Retrieved from http://www.iprbookshop. $\mathrm{ru} / 9056 . \mathrm{html}$

5. Bobyl, V. (2014). Використання показників рівня якості управління ризиками в процесі оцінювання фінансової стійкості банку [Vykorystannia pokaznykiv rivnia yakosti upravlinnia ryzykamy $v$ protsesi otsiniuvannia finansovoi stiikosti banku]. Retrieved from http://eadnurt.diit.edu.ua/ bitstream/123456789/2081/1/ Bobyl_11.pdf

6. Bobyl, V. (2014). Методика применения показателей системы риск-менеджмента [Metodika primeneniya pokazateley sistemy risk- menedzhmenta]. Bankauski Vesnik, 6, 67-74.

7. Boyd, J., \& Nicolo, G. (2005). The theory of bank risk taking and competition revisited. The Journal of Finance, 60(3), 1329-1343.

8. Carson, C. S., \& Ingves, S. (2001). Financial Soundness Indicators. Policy Paper, International Monetary Fund, June 4.

9. Cherep, A. V. et al. (2011). Проблеми та методи забезпечення фінансової стійкості комериійних банків [Problemy ta metody zabezpechennia finansovoi stiikosti komertsiinykh bankiv] (150 p.). Zaporizhzhia: ZNU.

10. Demirguc-Kunt, A., Detragiache, E., \& Tressel, T. (2006). Banking on the Principles: Compliance with Basel Core Principles and Bank Soundness (World Bank Policy Research Working Paper No. 3954) (pp. 3-33).

11. Diaconu, R.-I., \& Oane, D.-C. (2014). The Main Determinants of Bank's Stability. Evidence from Romanian Banking Sector. Procedia Economics and Finance, 16, 329-335. https://doi.org/10.1016/ S2212-5671(14)00810-7

12. Dovhan, Zh. M. (2012). Фінансова стійкість банківськоі системи України: проблеми оцінки та забезпечення [Finansova stiikist bankivskoi systemy Ukrainy: problem otsinky ta zabezpechennia] (448 p.). Sumy: UABS NBU.

13. Dziubliuk, O. V., \& Mykhailiuk, R. V. (2009). Фінансова стійкість банків як основа ебективного функціонування кредитної системи [Finansova stiikist bankiv yak osnova efektyvnoho funktsionuvannia kredytnoi systemy] (316 p.). Ternopil: TNEU.

14. Fetisov, G. G. (2002).

Методологические основы формирования устойчивости банковской системы [Metodologicheskiye osnovy formirovaniya ustoychivosti bankovskoy sistemy]. Finansy $i$ Kredit, 15(105), 2-13.

15. International Monetary Fund (2006). Financial Soundness Indicators: Compilation Guide. Retrieved from http://www.imf.org/ external/pubs/ft/fsi/guide/2006/ index.htm

16. Kliusko, L. A. (2013). Фінансова стійкість банків: теорія та методика оцінки [Finansova stiikist bankiv: teoriia ta metodyka otsinky] (246 p.). Irpin: NU DPS Ukrainy.

17. Kornyliuk, R. (2013). Методика рейтингу успішності українських банків [Metodyka reitynhu uspishnosti ukrainskykh bankiv]. Realna Ekonomika, 3.

18. Lavrushyn, O. I. (Ed.), Afanasieva, O. N., \& Kornienko, S. L. (2005). Банковское дело: современная система кредитования [Bankovskoye delo: sovremennaya sistema kreditovaniya] (256 p.). Moscow: KNORUS.

19. Lotobayeva, G., \& Nasonova, А. (2006). Система ключевых показателей устойчивости коммерческого банка [Sistema kliuchevykh pokazateley ustoychivosti kommercheskogo banka]. 
Sibirskaya Finansovaya Shkola (Aval), 4, 456-501.

20. Martinez-Miera, D., \& Repullo, R. (2010). Does competition reduce the risk of bank failure? Review of Financial Studies, 23(10), 3638-3664.

21. Marych, M. H., \& Marych, A. V. (2017). Оцінка фінансової стійкості комерційних банків України на сучасному етапі розвитку [Otsinka finansovoi stiikosti komertsiinykh bankiv Ukrainy na suchasnomu etapi rozvytku]. Hlobalni ta natsionaln problem ekonomiky, 17, 698-703.

22. Myronchuk, V. M. (2012). Використання функції Харрінгтона при оцінюванні фінансової стійкості банків України [Vykorystannia funktsii Kharrinhtona pry otsiniuvanni finansovoi stiikosti bankiv Ukrainy]. Ekonomika. Upravlinnia. Innovatsii, 1.

23. National Bank of Ukraine (2018) Retrieved from http://www.bank. gov.ua.

24. National Bank of Ukraine (n.d.). Економічні та фонансові показники України [Ekonomichni ta finansovi pokaznyky Ukrainy]. Retrieved from https://bank.gov. ua/control/uk/publish/article?art_ id $=36728 \&$ cat_id $=45692$

25. Panasenko, Н. (2009). Основні напрями забезпечення стабільності банківської системи України на иляху інтеграції у світовий фінансовий npocmip [Osnovni napriamy zabezpechennia stabilnosti bankivskoi systemy Ukrainy na shliakhu intehratsii u svatovyi finansovyi prostir]. Retrieved from http://experts.in.ua
26. Ramskyi, A. et al. (2017). Integration of Ukraine into the European banking system: cleaning, rebooting and Basel III. Banks and Bank Systems, 12(4), 163-174. http:// dx.doi.org/10.21511/bbs.12(41). 2017.05

27. Sheludko, N. (2002). Управління бінансовою стійкістю комериійних банків: монографія [Upravlinnia finansovoiu stiikistiu komertsiinykh bankiv] (228 p.). Kyiv: In-t ekonomiky.

28. Sheludko, N. M. (2000). До визначення фінансової стійкості комерційного банку [Do vyznachennia finansovoi stiikosti komertsiiniho banku]. Visnyk Natsionalnoho Banku Ukrainy, 3, 40-43.

29. Shermer, O. (2013).

Моделювання ризику та фінансової стійкості комериійного банку [Modeliuvannia ryzyku ta finansovoi stiikosti]. Retrieved from http://naub.oa.edu.ua/2013/ modelyuvannya-ryzyku-ta-finansovoji-stikostikomertsijnohobanku/

30. Shpakovska, N. I. (2013). Методичний підхід до оцінки фінансової стійкості банків [Metodychnyi pidkhid do otsinky finansovoi stiikosti bankiv]. Naukovyi Visnyk: Finansy, Banky, Investytsii, 3, 100-105.

31. Shulzhenko, A. A. (2012). Забезпечення фінансової стійкості банків на основі підвищення рівня капіталізаціі [Zabezpechennia finansovoi stiikosti bankiv na osnovi pidvyshchennia rivnia kapitalizatsii] (6 p.). Sumy: UABS NBU.

32. Swanepol, E., \& Smit, A. M. (2016). The impact of executive remuneration on risk-taking in the banking industry. Investment Management and Financial Innovations, 13(3). http://dx.doi. org/10.21511/imfi.13(3).2016.10

33. Vaskovych, I. M. (2006). Забезпечення фінансової стійкості банків Украӥни в умовах ринку: автореф. дис. [Zabezpechennia finansovoi stiikosti bankiv Ukrainy v umovakh rynku: avtoref. dys.] (19 p.). Lviv.

34. Vitlinskyi, V., \& Pernarivskyi, О. (2000). Фінансова стійкість як системна характеристика комерційного банку [Finansova stiikist yak systemna kharakterystyka komertsiinihi banku]. Bankivska sprava, 6, 48-51.

35. Zavadska, D. V. (2011).

Особливості забезпечення фінансової стійкості банків України [Osoblyvosti zabezpechennia finansovoi stiikosti bankiv Ukrainy]. In M. I. Zvieriakov (Ed.), Visnyk sotsialno-ekonomichnykh doslidzhen, 3(43), 73-80. Odesa: Odeskyi derzh. ekon. un-t.

36. Zveruk, L. A., \& Boieva, S. K. (2017). Концептуальні засади дослідження управління фінансовою стійкістю банківських установ [Kontseptualni zasady doslidzhennia upravlinnia finansovoiu stiikistiu bankivskykh ustanov]. Biznes Inform, 3, 288-293.

37. Zvieriakov, M. I., \& Kovalenko, V. V. (2012). Формування системи індикаторів фінансової стійкості банківської системи [Formuvannia systemy indykatoriv finansovoi stiikosti bankivskoi systemy]. Finansy Ukrainy, 4, 3-12. 